TITLE:

\title{
Inhibition of GIP signaling modulates adiponectin levels under high-fat diet in mice( Abstract_要旨)
}

$\operatorname{AUTHOR}(S)$ :

Naitoh, Rei

\section{CITATION:}

Naitoh, Rei. Inhibition of GIP signaling modulates adiponectin levels under high-fat diet in mice. 京都大学, 2009, 博士(医学)

ISSUE DATE:

2009-07-23

URL:

http://hdl.handle.net/2433/126440

RIGHT: 


\begin{tabular}{|l|l|c|l|}
\hline 京都大学 & 博士（医学） & 氏 名 & 内藤 玲 \\
\hline & \multicolumn{2}{|c|}{ Inhibition of GIP signaling modulates adipon }
\end{tabular}

論文題目 diet in mice

（GIP シグナルの遮断は高脂肪食負荷マウスにおけるアディポネクチンレベ ルを変化させる)

\section{(論文内容の要旨)}

インクレチンホルモンである gastric inhibitory polypeptide(GIP) は、膵 $\beta$ 細胞から のインスリン分泌を増加させる作用に加え、脂肪細胞における脂肪蓄積を促進寸る作用を 有する。高脂肪食負荷下での GIP 受容体欠損マウスは肥満を抑制し、肥満早期に肝臓や筋 肉での脂肪酸 $\beta$ 酸化が増加することが報告されている。しかし、肝臟、筋肉ではGIP 受容 体の発現は認められず、これらの未梢組織において脂肪酸 $\beta$ 酸化が増加寸る機序は明らか ではない。肝臓、筋肉などの未梢組織の脂肪酸 $\beta$ 酸化に関わる因子として脂肪から分泌さ れるレプチンやアディポネクチンなどのアディポカインがある。レプチン遺伝子が欠損し た 2 型糖尿病肥満モデルである ob/ob マウスにおいても GIP シグナルの遮断をおこなうと 23\%の体重減少が認められたことから、本研究は、アディポネクチンに注目し、GIP シグナ ル欠損による末梢組織での脂肪酸 $\beta$ 酸化との関連を検討した。

早期肥満状態を観察するため、GIP 受容体欠損マウスおよび野生型マウス (7 週歯) に高 脂肪食 ( $45 \%$ 脂肪食) または通常食 (11\%脂肪食) 負荷を 3 週間行った。GIP 受容体欠損マウス では、野生型マウスと比較して、高脂肪食負荷 3 週間後の内臟脂肪量は有意に減少してお り、脂肪酸 $\beta$ 酸化によるエネルギー消費量は有意に増加していた。また、GIP 受容体欠損 マウスにおける高脂肪食負荷 3 週間後の血清アディポネクチン濃度、脂肪組織におけるア ディポネクチン $\mathrm{mRNA}$ 発現量は、野生型マウスと比較して、有意に増加していた。高脂肪 食負荷野生型マウスでは、通常食負荷野生型マウスと比較し、内臟脂肪の増加とともに血 清アディポネクチン濃度、および脂肪組織におけるアディポネクチン mRNA 発現量の有意 な減少が認められた。一方、高脂肪食負荷GIP受容体欠損マウスでは、通常食負荷GIP受 容体欠損マウスと比較して、高脂肪食負荷による内臟脂肪の増加にもかかわらず、血清ア ディポネクチン濃度、及び脂肪組織におけるアディポネクチン mRNA 発現量の有意な増加 が認められた。血清アディポネクチンの質的な変化を確認寸るためウエスタンブロット法 を用いて検討したところ、6 量体(middle molecular weight)、およびそれ以下の低分子量 体 (low molecular weight) が、高脂肪食負荷 GIP 受容体欠損マウスにおいて、高脂肪食負 荷野生型マウスと比較して有意に増加していた。アディポネクチンの上流分子である peroxisome proliferator-activated receptor (PPAR) $\gamma$ mRNA 発現量は、高脂肪食負荷 GIP 受容体欠損マウスの白色脂肪において、通常食負荷 GIP 受容体欠損マウスおよび高脂肪食 負荷野生型マウスと比較して有意に増加したが、野生型マウスでは高脂肪食負荷により減 少寸る傾向が認められた。筋肉では、アディポネクチンの下流分子である PPAR $\alpha \mathrm{mRNA}$ 発 現量が、高脂肪食負荷 GIP 受容体欠損マウスにおいて、通常食負荷 GIP 受容体欠損マウス および高脂肪食負荷野生型マウスと比較して有意に増加し、acetyl-CoA carboxylase (ACC) mRNA 量は有意に減少していた。

以上より、高脂肪食による肥満の早期の段階では、GIP シグナルの遮断によりアディポ ネクチンレベルが上昇し、そのことが末梢組織での脂肪酸 $\beta$ 酸化を克進させ、肥満を抑制 する一因となっている可能性が示唆された。
（論文審査の結果の要旨）

Gastric inhibitory polypeptide(GIP)は、膵 $\beta$ 細胞からのインスリン分泌を増加させる インクレチン作用に加え、脂肪細胞へのエネルギ一蓄積を促進する作用を有する。GIP 受容体欠損マウスおいて、高脂肪食負荷による肥満が抑制され、肥満早期に未梢組織で の脂肪消費が増加することが報告されている。しかし、未梢組織において脂肪酸 $\beta$ 酸化 が増加し、脂肪が消費される機序は明らかではない。

申請者は、脂肪酸 $\beta$ 酸化に関わる分子としてアディポネクチンに注目し、GIPシグナル久 損による末梢組織での脂肪消費との関連を検討した。高脂肪食による肥満早期の段階で は、GIPシグナル欠損により、脂肪組織内のアディポネクチンmRNA発現量が増加し、 また血清中のアディポネクチンが増加することを明らかにした。さらに骨格筋において

$\operatorname{PPAR} \alpha$ のRNA発現量が増加することから、アディポネクチンの増加によって、脂肪 酸 $\beta$ 酸化が増加し、肥満早期の体重増加に対して抑制的に作用寸る可能性が示唆された。 以上の研究は、GIPの催肥満作用の解明に貢献し、糖尿病学の発展に寄与寸るところが多 w。

したがって、本論文は博士(医学)の学位論文として価值あるものとみとめる。

なお、本学位授与申請者は、平成 21 年 5 月 11 日実施の論文内容とそれに関連した試問を 受け、合格と認められたものである。 